\title{
ŚWIADOMOŚĆ SAMOPOCZUCIA ZDROWOTNEGO STUDENTÓW W KONTEKŚCIE ZAGROŻEŃ ZDROWIA PSYCHICZNEGO
}

\section{AWARENESS OF STUDENTS` HEALTH WELL-BEING IN THE CONTEXT OF MENTAL HEALTH RISKS}

\author{
Izabella M. Lukasik ${ }^{1(\mathrm{~A}, \mathrm{C}, \mathrm{D}, \mathrm{E}, \mathrm{F}, \mathrm{G})}$, Anna Witek ${ }^{1(\mathrm{~A}, \mathrm{~B}, \mathrm{D}, \mathrm{E}, \mathrm{F}, \mathrm{G})}$ \\ ${ }^{1}$ Zakład Pedeutologii i Edukacji Zdrowotnej, Wydział Pedagogiki i Psychologii, \\ Uniwersytet Marii Curie-Skłodowskiej w Lublinie
}

Łukasik, I.M., Witek, A. (2017). Świadomość samopoczucia zdrowotnego studentów w kontekście zagrożeń zdrowia psychicznego. Rozprawy Społeczne, 11(4), 64-72. https://doi.org/10.29316/rs.2017.40

Wkład autorów:

A. Zaplanowanie badań

B. Zebranie danych

D. Interpretacja danych

E. Przygotowanie artykułu

F. Wyszukiwanie i analiza literatury

G. Zebranie funduszy
C. Dane - analiza i statystyki

\begin{abstract}
Streszczenie
Wstęp. Za cel badań uznano wskazanie istnienia zależności między zdrowiem psychicznym studentów a ich świadomością samopoczucia zdrowotnego.

Materiał i metody. Badaniami objęto grupę 71 studentów pedagogiki. Zastosowano narzędzia badawcze: kwestionariusz konstrukcji własnej, Kwestionariusz Ogólnego Stanu Zdrowia - GHQ-28. Wyniki. Świadomość dobrego samopoczucia fizycznego, psychicznego i społecznego rzadko współwystępuje z problemami w zdrowiu psychicznym. Dobre samopoczucie fizyczne nie chroniło przed pojawieniem się ryzyka wystąpienia zaburzeń psychicznych. Lepszemu samopoczuciu fizycznemu i psychicznemu towarzyszyła mniejsza ilość symptomów somatycznych. Im wyższa świadomość dobrego samopoczucia psychicznego i społecznego tym mniejszy poziom niepokoju i rzadsze występowanie bezsenności. Im lepsze samopoczucie stanu zdrowia społecznego i psychicznego, tym rzadsze występowanie zaburzeń funkcjonowania. Lepsze samopoczucie psychiczne rzadziej współwystępuje z depresją.

Wnioski. Dobre samopoczucie fizyczne, psychiczne i społeczne może sugerować istnienie lepszego stanu zdrowia psychicznego. Jednak fakt, iż prawdopodobieństwo wystąpienia zaburzeń psychicznych dotyka co dziesiątego badanego (9,8\% badanych) budzi niepokój. Wyniki potwierdzają konieczność prowadzenia edukacji zdrowotnej skoncentrowanej na radzeniu sobie z problemami zdrowia psychicznego.
\end{abstract}

Słowa kluczowe: świadomość samopoczucia fizycznego, psychicznego i społecznego, zdrowie psychiczne

\section{Summary}

Introduction. The purpose of the study was to identify the relationship between self-esteem in physical, mental and social health and control of emotions and mental health expressed by somatic symptoms, anxiety, insomnia, difficulty in fulfilling professional duties and emerging depressive symptoms.

Material and methods. The study covered a group of 71 students of pedagogy. Following research tools were used: CECS Emotional Control Scale, self-built questionnaire, General Health Questionnaire - GHQ.

Results. Assessment of physical, mental and social health was associated with the presence of somatic symptoms and the probability of mental health disorders. Men overestimate their state of health. Patients who control their anger manifest fewer depressive symptoms and they function better in daily tasks.

Conclusions. Individuals who assess their health not necessarily as satisfactory reveal behaviour that can be treated as a probability of mental disorder (9.8\%). These findings are disquieting and they confirm the need for health education that is focused on mental health problems.

Ryciny: 3

Literatura: 37

Otrzymano: czerwiec 2017

Zaakceptowano: październik 2017

\section{Wstęp}

Świadomość zdrowotna stanowi pojęcie niedookreślone, z racji niemożności przyjęcia jednoznacznego desygnatu. Częściej wiąże się z potocznością myśle- nia i koniecznością codziennego oceniania własnego dobrostanu o charakterze fizycznym, psychicznym czy społecznym. Próbę ustalenia definicji świadomości zdrowotnej podjęła Elżbieta Korzeniowska (1997, s. 57), która uznała za Kojderem (1976), że jest to poję-

Adres korespondencyjny:Izabella M. Łukasik, Zakład Pedeutologii i Edukacji Zdrowotnej, Wydział Pedagogiki i Psychologii, Uniwersytet Marii Curie-Skłodowskiej w Lublinie, ul. Narutowicza 12, 20-153 Lublin, e-mail: izabella.lukasik@poczta.umcs.lublin.pl, tel. +48 815376323

Copyright by: Państwowa Szkoła Wyższa im. Papieża Jana Pawła II w Białej Podlaskiej, Izabella M. Łukasik, Anna Witek

Czasopismo Open Access, wszystkie artykuły udostępniane są na mocy licencji Creative Commons Uznanie autorstwa-użycie niekomercyjne-na tych samych warunkach 4.0 Międzynarodowe (CC BY-NC-SA 4.0, http://creativecommons.org/licenses/by-nc-sa/4.0/). 
cie z pogranicza nauk i ma charakter zbitki pojęciowej. Najważniejszym zabiegiem stało się określenie zakresu problemów odnoszących się do sfery rzeczywistości zdrowia. Korzeniowska (1997, s. 58) uwzględniła: 1) rozumienie zdrowia, 2) stan zdrowia, w tym autoocena i kryteria jego oceny, 3) uwarunkowania zdrowia, ich rodzaj, siłę i charakter wpływu na zdrowie oraz możliwość i oddziaływanie na nie przez człowieka, 4) wartościowanie zdrowia. Z kolei Cisek, Gniadek, Richter, Chmiel (2004, s. 103) przyjęły iż „świadomość zdrowotna obejmuje ogólną wiedzę na temat czynników i zachowań mających wpływ na zdrowie, a pośrednio także przekonanie o możliwości wpływu na własne zdrowie, motywację i umiejętność podejmowania działań prozdrowotnych". Natomiast Krzysztof Puchalski (1997) zwraca uwagę na istnienie nieświadomości zdrowotnej, w momencie kiedy wartość zdrowia zostanie zdominowana przez inne wartości i wskazuje się na inne cele życiowe sprzyjające podniesieniu samooceny. Problemy zdrowia są wypierane poza świadomość, zwłaszcza kiedy eksponowane są uwarunkowania zdrowotne wymykające się kontroli jednostki.

Hyehyum Hong (2011) podkreśla, że ludzie z wysokim poziomem świadomości zdrowotnej są podatni na interwencję, mają największą szansę kształtowania prawidłowych zachowań zdrowotnych. Analizując różne definicje świadomości zdrowotnej przytaczane przez badaczy w ciągu ostatnich 20 lat dostrzegł, że konsekwentnie pojawiają się takie elementy jak: 1) integrowanie zachowań zdrowotnych, 2) zwrócenie uwagi na własne zdrowie, 3) poszukiwanie informacji i ich zastosowanie, 4) osobista odpowiedzialność za stan swojego zdrowia, 4) motywacja do zajęcia się zdrowiem. Hong przygotowując Scale Development for Measuring Health Consciousness, wykorzystał itemy skal prezentowane przez innych badaczy: Kraft, Goodell 1993; Jayanti, Burns 1998; Gould 1988; Michaelidou, Hassan 2008; Dutta-Bergman 2004; 2005, 2006, Dutta 2007; Furnham, Forey 1994; Tai, Tam 1997. Skala składająca się z 11 itemów nawiązuje do ujęcia świadomości zdrowotnej jako orientacji w kierunku ogólnego stanu zdrowia, a nie problemów zdrowotnych. Przy tym poziom świadomości zdrowia określają trzy składowe: samoświadomość zdrowia, osobista odpowiedzialność, motywacja zdrowia.

Gould (1998, 1999 za: Hong, 2011, s. 8) rozważał świadomość zdrowotną wyłącznie jako stan psychiczny lub wewnętrzny osoby, w tym czujność zdrowia, samoświadomość zdrowotną, zaangażowanie w ochronę zdrowia i samokontrolę własnego zdrowia. Świadomość jego zdaniem niekoniecznie musi być zintegrowana $\mathrm{z}$ konkretnymi zachowaniami zdrowotnymi. Hong sugeruje, że wymienione przez Goulda domeny powinny być uzupełnione o osobistą odpowiedzialność i motywację zdrowotną. Alternatywną nazwą dla świadomości zdrowotnej Gould a jest świadomość samopoczucia. Przyjęcie takiego określenia zbliża do ujęcia zdrowia jako dobrostanu fizycznego, psychicznego, społecznego a nie tylko braku choroby lub niepełnosprawności, czyli definicji zdrowia. W obecnej pracy przyjęto określenie świadomości samopoczucia fizycznego, psychicznego i społecznego.

Zdrowie psychiczne najsilniej wydaje się być powiązane $\mathrm{z}$ dobrostanem o charakterze psychicznym. Pamiętać należy, że poruszając problem zdrowia psychicznego dotykamy nie tylko sfery poznawczej, ale (może nawet przede wszystkim) emocjonalnej. Weare, Gray (1996 za: Woynarowska, 2017, s. 24) komponent poznawczy uznają za zdrowie umysłowe, określone jako zdolność do jasnego, spójnego myślenia, uczenia się, rozwoju swego potencjału intelektualnego. Drugi komponent afektywny, czyli emocjonalny to zdolność do kontrolowania emocji, rozpoznawania ich i wyrażania w sposób adekwatny do sytuacji, zapewniający poczucie komfortu i akceptowany społecznie. Ponadto jest to zdolność do radzenia sobie z trudnościami, stresem, napięciami, depresją i lękiem.

Przeżycia pochodzą $\mathrm{z}$ różnych źródeł, zarówno somatycznych, psychicznych jak i duchowych (transpersonalnych). Impulsy cielesne dotyczą percepcji zewnętrznej (eksterocepcji), którą reprezentuje zmysł wzroku, słuchu, powonienia, smaku i dotyku oraz percepcji wewnętrznej (interocepcji), gdzie mamy do czynienia ze zmysłem ruchu, doznań napięciowych mięśni, funkcjonowania organów wewnętrznych, temperatury ciała. Wundt uważał, że uczucia są szczególnym stanem świadomości. Świadomość zaś posiada trzy wymiary uczuciowe: chęć/ niechęć, odprężenie/napięcie, spokój/podniecenie (Vedfelt, 2001). Wczuwając się w sygnały ciała można te stany odczuć. Jak bardzo przeżywane uczucia, stres, emocje wpływają na nasz stan zdrowia zaświadcza obecność chorób o charakterze psychosomatycznym. Emocje są nieodłącznym elementem codzienności. Zdaniem Carvera (1998) w trakcie każdego dnia doświadczamy epizodów lęku, smutku, gniewu i radości. Badania prowadzone przez Frijda, Kuipers, Terschure, (1989) potwierdziły, że poszczególnym emocjom towarzyszą charakterystyczne wzorce oceny poznawczej sytuacji oraz odczuwanych tendencji do działania. Emocje są często traktowane jako wieloskładnikowe procesy, syndromy reakcji. Przedstawicielem komponentowego sposobu definiowania emocji jest Scherer (1984), który wskazuje na wieloskładnikową naturę emocji, ale jednocześnie widzi możliwość wyodrębniania poszczególnych emocji poprzez opisanie specyficznego wzorca, układu komponentów. Podobnie Lazarus (1991, za: Łosiak, 2007, s.22), określa emocje jako system wzajemnie od siebie zależnych procesów, wśród których najważniejsze to ocena poznawcza, impulsy do działania i wzorzec reakcji somatycznych.

Zdaniem Jamesa (1890) a później Mandlera (1984), Damasio (1999) emocje zawsze wywołują zmiany w ciele. Lazarus (1991), Izard (1980), Frijda (1986) zaliczają aktywność autonomicznego układu nerwowego wraz z pojawiającymi się zmianami w narządach wewnętrznych do obserwowanych wskaźników emocji. Wspomniane zmiany określane są jako wzorzec reakcji somatycznych. Stanowią one integral- 
ny składnik emocji i manifestują się skurczami żołądka, napięciem mięśni, przyśpieszonym biciem serca. Stąd emocje spostrzegane są jako procesy zarówno psychiczne, jak i somatyczne (za: Łosiak, 2007).

Doznania i przeżycia, jakich szukamy w epoce społeczeństwa doznań zawierają w sobie obok komponentu fizjologicznego także kognitywny. Gerhard Schulze, twórca koncepcji „społeczeństwa doznań”, spostrzega emocje jako konstrukty poznawcze ukształtowane w kontekście społecznym. Pierwotne ramy poznawcze kierunkują ludzi w ich dalszych życiowych poszukiwaniach, na które mają wpływ różne schematy kulturowe. Pełne i satysfakcjonujące przeżycia pojawiają się, gdy zdarzenia, aktywność i nabywane dobra są spójne z życiową filozofią jednostki (za: Sieradzki, 2014, s.157).

Radzenie sobie z emocjami ma znaczący wpływ na ludzkie zdrowie, zapewniając większą energię i witalność, gdyż uczucia jako zjawiska fizyczne przemawiają do człowieka poprzez funkcjonowanie jego narządów wewnętrznych i mięśni. Osoby odczuwające poczucie niezrozumienia, zagubienia, jałowości życia, nadmiernie pobudzone emocjonalnie mają skłonność do przejadania się, przesadnie dbają o porządek, ulegają manii zakupów lub przepracowują się, popadają m.in. w uzależnienia oraz chorują na choroby o podłożu somatycznym (Michalska 2004, s. 33).

Uczucia manifestują się w ludzkim organizmie w postaci zmian fizjologicznych, mimicznych i ruchowych. Gdy nie chcemy odczuwać uczuć, wówczas zaciskamy zęby, wstrzymujemy oddech, napinamy mięśnie, kurczymy narządy wewnętrzne. Wstrzymywanie w taki sposób bólu emocjonalnego powróci po jakimś czasie w postaci na przykład chronicznego bólu fizycznego i chorób somatycznych (Segal, 1997). Jednostka uskarżać się może na migreny, bóle żołądka i krzyża, wrzody, katary, sztywność szyi, astmę, bezsenność. Zdaniem Segal (1997) mogą to być symptomy nagromadzonych uczuć domagających się uświadomienia. Do konsekwencji tzw. analfabetyzmu emocjonalnego możemy zaliczyć również działania kompulsywne i uzależniające. Szczególnie niebezpieczne dla zdrowia i życia młodych ludzi jest nadużywanie alkoholu oraz substancji uzależniających i stosowanie używek jako lekarstwa, dającego ukojenie dla przeżywanych uczuć: niepokoju, lęku, złości, depresji. Głęboko zakorzeniony lęk przed emocjami sprawia, że człowiek uczy się wyzbywania ich, a nie przekształcania w bardziej dojrzale (Michalska, 2004). Niewyrażone emocje niekorzystnie wpływają na stan zdrowia, stąd ich wyrażanie jest zalecane między innymi w psychoterapii (Czapiński, 2008, Solovey, Mayer, Caruso, 2008).

\section{Materiał i metody}

Przedmiotem badań uczyniono określenie świadomości samopoczucia zdrowotnego młodych dorosłych, zaś problem badawczy dotyczył obserwacji, na ile samopoczucie fizyczne, psychiczne, społeczne może być rodzajem predyktora dla spostrzegania zdrowia psychicznego.
Za cel badań uznano wskazanie istnienia związku między świadomością samopoczucia zdrowotnego a zdrowiem psychicznym badanych studentów. W badaniach przyjęto, iż świadomość samopoczucia zdrowotnego zostanie określona poprzez samoocenę stanu zdrowia w wymiarze: fizycznym, psychicznym i społecznym. Zdrowie psychiczne zostało wyrażone poprzez wskazanie symptomów somatycznych, niepokój i bezsenność, trudności z wypełnianiem obowiązków zawodowych lub pojawiające się symptomy depresyjne.

Zmienna zależna to świadomość samopoczucia zdrowotnego, określona wskaźnikami zawartymi w odpowiedziach na pytania autorskiego kwestionariusza. Za zmienną niezależną przyjęto: możliwość wystąpienia zaburzeń psychicznych (wskaźnikiem wynik badań z wykorzystaniem Kwestionariusza GHQ-28, z czterema podskalami: symptomy somatyczne; niepokój, bezsenność; zaburzenia funkcjonowania; symptomy depresyjne).

Sformułowano następujące pytania badawcze:

1. Czy, a jeśli tak, to jakiego rodzaju zależność istnieje między świadomością samopoczucia fizycznego, psychicznego, społecznego a ogólnym stanem zdrowia psychicznego?

2. Czy, a jeśli tak, to jakiego rodzaju zależność istnieje między świadomością samopoczucia fizycznego, psychicznego, społecznego a prawdopodobieństwem wystąpienia zaburzeń psychicznych?

3. Czy, a jeśli tak, to jakiego rodzaju zależność istnieje między świadomością samopoczucia fizycznego, psychicznego, społecznego a odczuwaniem symptomów somatycznych?

4. Czy, a jeśli tak, to jakiego rodzaju zależność istnieje między świadomością samopoczucia fizycznego, psychicznego, społecznego a niepokojem i bezsennością?

5. Czy, a jeśli tak, to jakiego rodzaju zależność istnieje między świadomością samopoczucia fizycznego, psychicznego, społecznego a zaburzonym funkcjonowaniem?

6. Czy, a jeśli tak, to jakiego rodzaju zależność istnieje między świadomością samopoczucia fizycznego, psychicznego, społecznego a występowaniem zaburzeń depresyjnych?

Odnosząc się do powyższych pytań badawczych postawiono następujące hipotezy:

1. Świadomość samopoczucia zdrowotnego, pozwalająca określić stan zdrowia w wymiarze fizycznym, psychicznym, społecznym jest związana z ogólnym stanem psychicznym

Jeśli stan psychiczny uległ załamaniu czasowemu czy długookresowemu w wyniku doświadczania trudności, problemów lub na skutek choroby psychicznej należy spodziewać się, że pojawi się złe samopoczucie zdrowia.

2. Świadomość samopoczucia zdrowotnego, pozwalająca określić stan zdrowia w wymiarze fizycznym, psychicznym, społecznym jest związana z prawdopodobieństwem wystąpienia zaburzeń psychicznych. 
Przyjęcie powyższej hipotezy jest podyktowane faktem, iż ujęcie holistyczne zdrowia pozwala na uznanie wzajemnych uwarunkowań i powiązań $\mathrm{w}$ obrębie organizmu, traktowanego z pozycji ciała-umysłu-ducha (Bishop, 2000, Szyszko-Bohusz, 2013; Łukasik, 2011; Ostrzyżek, Marcinowski, 2012; Starzyńska-Kościuszko, 2010). Etiologia zaburzeń psychicznych dowodzi różnorodnych wpływów i zależności, nie tylko o charakterze biologicznym.

3. Świadomość samopoczucia fizycznego i psychicznego jest związana z odczuwaniem symptomów somatycznych.

Potwierdzeniem dla tej tezy jest obecność chorób o charakterze psychosomatycznym. Przegląd psychologicznych aspektów procesu powstawania, utrzymywania się i zapobiegania różnorodnym przewlekłym chorobom i zaburzeniom funkcjonowania somatycznego umacnia w przekonaniu o ogromnej złożoności procesu (Gałecki, Orzechowska, 2014; Freyberger, Schneider, Stieglitz, 2005).

4. Świadomość samopoczucia psychicznego jest związana z odczuwaniem niepokoju i bezsennością.

Bezsenność i niepokój współwystępuje z wieloma symptomami zaburzeń psychicznych. Osoba mająca tego typu problemy przede wszystkim odczuwa zmęczenie, podenerwowanie, co zmusza ją do oceny stanu swojego zdrowia psychicznego jako nieodpowiedniego. George Vaillant (2012) uwzględnia różne modele pozytywnego zdrowia psychicznego. Jednak pojęcie zdrowia psychicznego jest związane z koncepcją dobrostanu psychicznego. Uwzględnić należy różne wymiary psychologiczne: pozytywną samoocenę, poczucie ciągłego wzrostu i rozwoju, przekonanie, że życie ma cel i sens, posiadanie dobrych relacji z innymi, zdolność sprawnego kierowania własnym życiem, oraz poczucie samodeterminacji. Poziom tych wymiarów często bywa obniżony u osób z zaburzenia nastroju lub zaburzeniami lękowymi, a te kojarzone są z występowaniem bezsenności.

5. Świadomość samopoczucia zdrowia w wymiarze społecznym jest związana z zaburzonym funkcjonowaniem społecznym.

Zaburzenia natury psychicznej rzutują na funkcjonowanie jednostki w grupie, pełnienie ról, wykonywanie codziennych zadań. Percepcja funkcjonowania społecznego przez osobę nie zawsze jest adekwatna do sytuacji (Rymaszewska, Dobrzyńska, Kiejna, 2006).

6. Świadomość samooceny psychicznej jest związana z występowaniem objawów depresyjnych.

W przypadku zaburzeń depresyjnych znaczenie maja następujące czynniki psychologiczne: wybrane cechy osobowościowe, przekonania i oczekiwania, wsparcie społeczne, strategie radzenia sobie z sytuacją trudną oraz ryzyko zachowań suicydalnych (Michalska-Leśniewicz, Gruszczyński, 2010). Samoocena własnego zdrowia psychicznego może być istotnym wskazaniem prawdopodobieństwa wystąpienia depresji.

Badania własne przeprowadzono w marcu 2017 roku wśród studentów pedagogiki, studiów licen- cjackich. Przebadano 71 osób, wiek badanych mieści się w przedziale: 19-25 lat. Uzyskane wyniki stanowią część działań zaplanowanych na potrzeby projektu realizowanego w 2016 roku w ramach badań statutowych. Odwołano się do rozumienia zdrowia jako dobrostanu w wymiarze fizycznym, psychicznym i społecznym. Badani dokonywali oceny własnego stanu zdrowia w tych kategoriach. Do określenia świadomości samopoczucia zdrowotnego badanych osób wykorzystano Kwestionariusz konstrukcji własnej, który pozwala poznać odczucia psychosomatyczne, odczuwanie bodźców o charakterze psychicznym i fizycznym. Kwestionariusz zbudowany jest z 10 pytań o różnym charakterze. Pytania otwarte dotyczyły rozumienia pojęcia świadomości zdrowotnej, występowania chorób przewlekłych oraz konsultacji lekarskich. Z uwagi na problemy badawcze najistotniejsze były trzy itemy: 1) Mój stan zdrowia fizycznego mogę określić jako dobry (tak, raczej tak, raczej nie, nie). 2) Mój stan zdrowia psychicznego mogę określić jako dobry (tak, raczej tak, raczej nie, nie). 3) Mogę określić moje relacje społeczne, poczucie wsparcia społecznego i stopień zaangażowania $w$ życie społeczne jako dobre (tak, raczej tak, raczej nie, nie). Z kolei Kwestionariusz Ogólnego Stanu Zdrowia-GHQ-28, autorstwa Dawida Goldberga służy do oceny stanu zdrowia psychicznego osób dorosłych. Wersja GHQ-28 oprócz informacji o ogólnym stanie zdrowia psychicznego, zawiera cztery skale pozwalające zdobyć dane o: objawach somatycznych, niepokoju i bezsenności, zaburzeniach funkcjonowania społecznego i objawach depresyjnych, (Makowska i in. 2001). Podskale reprezentują wymiary symptomatologii i niekoniecznie korespondują z diagnozą psychiatryczną. (Ocena..., 2001, s. 66). Badania trafności prowadzone były przez różnych badaczy w różnych krajach. Czułość określona na podstawie 43 badań wynosi na 84/77,89\%, rzetelność 0,92.

\section{Wyniki}

W badaniach własnych poproszono studentów o zdefiniowanie świadomości zdrowotnej. Większość koncentrowała się na wiedzy o stanie zdrowia: „Świadomość zdrowotna to szeroka wiedza o zdrowym stylu życia, o sposobach zapobiegania czynnikom wpływającym negatywnie na zdrowie, wiedza determinująca właściwe z punktu widzenia zdrowia, wybory żywieniowe oraz profilaktykę" (ankieta nr 3), „Wiedza na temat zdrowia psychicznego, fizycznego oraz społecznego, umiejętność profilaktyki zdrowotnej i zapobiegania chorobom” (ankieta nr 19), „Wiedza na temat tego co jest dobre dla człowieka w sensie fizycznym, jak i też psychicznym, tzn. wiedza o tym, że należy zdrowo się odżywiać, wychodzić na świeże powietrze, dbanie o to by czuć się psychicznie dobrze, otaczać się osobami o zdrowym i pozytywnym podejściu do życia” (ankieta nr 46), „Znajomość konsekwencji wpływów różnorodnych czynników społecznych i środowiskowych na jednostkę" (ankieta nr 54). Niektórzy badani odwoływali się do odczuwanego 
stanu: „Poczucie tego, kiedy czujesz się dobrze, kiedy źle. Zalecane badania, kiedy muszę je zrobić. Jaki jest mój stan zdrowia” (ankieta nr 24), „Poczucie, iż znamy swój stan zdrowia, wiemy, co jest korzystne dla naszego organizmu, a co nie” (ankieta nr 30), „Poczucie odpowiedzialności za własne zdrowie oraz posiadanie wiedzy na temat własnego stanu zdrowia" (ankieta nr 10), „Nie lekceważenie objawów jakie wysyła nam ciało, zaspokojenie jego potrzeb, dbanie o nie i o zdrowie psychiczne" (ankieta nr 6). Inni rozszerzali pojęcie świadomości o pewne treści: „Świadomość odnośnie chorób i zagrożeń, które wynikają z predyspozycji genetycznych, kulturowych a także sami stwarzamy poprzez zachowania ryzykowne, styl życia itp. Oznacza to, że pamiętamy o badaniach kontrolnych, wizytach u lekarzy, mamy świadomość, iż możemy na coś zachorować, wiemy gdzie szukać pomocy” (ankieta nr 28), „Świadomość społeczeństwa na temat zdrowego odżywiana się i prowadzenia zdrowego trybu życia. Jest to również świadomość każdego człowieka o swoim stanie zdrowia” (ankieta nr 1), „Bycie świadomym tego jak nasze czyny (czyli np. to co jemy, pijemy, czy jesteśmy aktywni fizycznie) wpływają na stan naszego zdrowia" (ankieta nr 5). W ramach badań profilaktycznych i dbania o swoje zdrowie studenci w ciągu ostatniego roku odwiedzali różnych specjalistów: stomatologa (61 osób), ginekologa (52), okulistę (44), dermatologa (28), kardiologa (26), chirurga (24), ortopedę (20), a także urologa, laryngologa, gastrologa, proktologa, psychiatrę, endokrynologa, neurologa, alergologa.

Interesującym problemem było określenie, na ile samoocena zdrowia we wskazanych trzech obszarach: fizycznym, psychicznym i społecznym jest związana z symptomami somatycznymi, niepokojem i bezsennością, zaburzonym funkcjonowaniem społecznym, objawami depresyjnymi.

Tabela 1. Związek świadomości samopoczucia zdrowotnego ze stanem zdrowia psychicznego, określonego Kwestionariuszem GHQ-28, N=71.

\begin{tabular}{|l|l|l|l|l|l|}
\hline \multirow{2}{*}{$\begin{array}{c}\text { Samoocena } \\
\text { stanu zdrowia- } \\
\text { wymiary: }\end{array}$} & \multicolumn{1}{c|}{$\begin{array}{c}\text { Ogólny stan } \\
\text { zdrowia } \\
\text { psychicznego }\end{array}$} & \multicolumn{1}{|c|}{$\begin{array}{c}\text { Objawy } \\
\text { somatyczne }\end{array}$} & $\begin{array}{c}\text { Niepokój } \\
\text { i bezsenność }\end{array}$ & $\begin{array}{c}\text { Zaburzenia } \\
\text { funkcjonowania }\end{array}$ & \multicolumn{1}{c|}{$\begin{array}{c}\text { Symptomy } \\
\text { depresyjne }\end{array}$} \\
\cline { 3 - 6 } fizyczny & $\begin{array}{l}\tau=-0,252 \\
\mathrm{p}<0,05\end{array}$ & $\begin{array}{l}\tau=-0,323 \\
\mathrm{p}<0,01\end{array}$ & $\begin{array}{l}\tau=-0,182 \\
n . i\end{array}$ & $\begin{array}{l}\tau=-0,083 \\
n . i\end{array}$ & $\begin{array}{l}\tau=-0,069 \\
n . i\end{array}$ \\
\hline psychiczny & $\begin{array}{l}\tau=-0,401 \\
\mathrm{p}<0,001\end{array}$ & $\begin{array}{l}\tau=-0,257 \\
\mathrm{p}<0,05\end{array}$ & $\begin{array}{l}\tau=-0,352 \\
\mathrm{p}<0,001\end{array}$ & $\begin{array}{l}\tau=-0,243 \\
\mathrm{p}<0,05\end{array}$ & $\begin{array}{l}\tau=-0,359 \\
\mathrm{p}<0,001\end{array}$ \\
\hline społeczny & $\begin{array}{l}\tau=-0,300 \\
\mathrm{p}<0,01\end{array}$ & $\begin{array}{l}\tau=-0,073 \\
\mathrm{n} . \mathrm{i}\end{array}$ & $\begin{array}{l}\tau=-0,255 \\
\mathrm{p}<0,05\end{array}$ & $\begin{array}{l}\tau=-0,352 \\
\mathrm{p}<0,001\end{array}$ & $\begin{array}{l}\tau=-0,341 \\
\mathrm{p}<0,001\end{array}$ \\
\hline
\end{tabular}

Źródło: opracowanie własne.

Istotny statystycznie okazał się związek świadomości samopoczucia fizycznego, psychicznego i społecznego z ogólnym stanem zdrowia psychicznego (tabela 1). Została potwierdzona hipoteza pierwsza, mówiąca o tym, że świadomość samopoczucia zdrowotnego, pozwalająca określić stan zdrowia we wskazanych trzech wymiarach jest związana z ogólnym stanem psychicznym.

Potwierdzona została hipoteza trzecia, zakładająca, że świadomość samopoczucia fizycznego i psychicznego jest związana z odczuwaniem symptomów somatycznych. Korelacje mają charakter odwrócony. Lepsze samopoczucie fizyczne współwystępuje z mniejszą ilością symptomów somatycznych ( $\tau=$ -0,323; p<0,01). Także wyższa świadomość samopoczucia psychicznego współwystępuje z mniejszą ilością objawów somatycznych $(\tau=-0,257 ; p<0,05)$.

Potwierdzona została hipoteza czwarta. Świadomość samopoczucia psychicznego jest związana z odczuwaniem niepokoju i bezsennością $(\tau=-0,352$; $\mathrm{p}<0,001)$. Im wyższa świadomość dobrego samopoczucia psychicznego tym mniejszy poziom niepokoju i rzadsze występowanie bezsenności. Ponadto okazało się, że także świadomość samopoczucia społecznego jest związana $\mathrm{z}$ odczuwaniem niepokoju i bezsennością $(\tau=-0,255 ; p<0,05)$. Im wyższa świa- domość dobrego samopoczucia społecznego tym mniejszy poziom niepokoju i rzadsze występowanie bezsenności.

Potwierdzona została hipoteza piąta, iż świadomość samopoczucia zdrowia w wymiarze społecznym jest związana z zaburzonym funkcjonowaniem społecznym ( $\tau=-0,352 ; p<0,001)$. Im lepsze samopoczucie stanu zdrowia społecznego, tym rzadsze występowanie zaburzeń funkcjonowania. Okazało się ponadto, że lepsze samopoczucie psychiczne rzadziej współwystępuje z zaburzeniami funkcjonowania $(\tau=-0,352 ; p<0,001)$.

Potwierdzona została hipoteza szósta, iż świadomość samooceny psychicznej jest związana z występowaniem objawów depresyjnych $(\tau=-0,359 ; p<0,001)$. Lepsze samopoczucie psychiczne rzadziej współwystępuje z depresją. Ponadto wskazano, że depresja rzadziej objawia się przy dobrym samopoczuciu w obszarze zdrowia społecznego $(\tau=-0,341 ; p<0,001)$.

W dalszej kolejności analizie poddano problem istnienia zależności między świadomością samopoczucia we wskazanych trzech wymiarach a prawdopodobieństwem wystąpienia zaburzeń psychicznych. Przytoczone przez badanych objawy mogą sugerować wystąpienie w przyszłości zaburzeń psychicznych. 
Tabela 2. Zależność między świadomością samopoczucia zdrowotnego-ujętego w dwie kategorie dobre/raczej dobre, złe/raczej złe a ryzykiem wystąpienia zaburzeń psychicznych z wykorzystaniem Kwestionariusza GHQ-28, N= 71 .

\begin{tabular}{|c|c|}
\hline Świadomość samopoczucia zdrowotnego & Ryzyko wystąpienia zaburzeń psychicznych \\
\hline fizycznego & $\mathrm{chi}^{2}=3,731 ; \mathrm{df}=1, \mathrm{p}<0,05 \quad \mathrm{C}=0,223 ; \mathrm{p}<0,05$ \\
\hline psychicznego & $\mathrm{chi}^{2}=0,717 ; \mathrm{df}=1 ; \mathrm{p}>0,05 \quad \mathrm{C}=0,100 ; \mathrm{p}=\mathrm{n} . \mathrm{i}$ \\
\hline społecznego & $\mathrm{chi}^{2}=1,942 ; \mathrm{df}=3 ; \mathrm{p}>0,05 \quad \mathrm{C} 0,163 ; \mathrm{p}=\mathrm{n} . \mathrm{i}$ \\
\hline
\end{tabular}

Źródło: opracowanie własne.

Hipoteza druga została tylko częściowo potwierdzona. Istnieje istotna statystycznie zależność między stanem zdrowia w wymiarze fizycznym a prawdopodobieństwem wystąpienia zaburzeń psychicznych $\left(\mathrm{chi}^{2}=3,731 ; \mathrm{df}=1, \mathrm{p}<0,05\right)$. Siła związku ma charakter umiarkowany $(C=0,223 ; p<0,05)$.

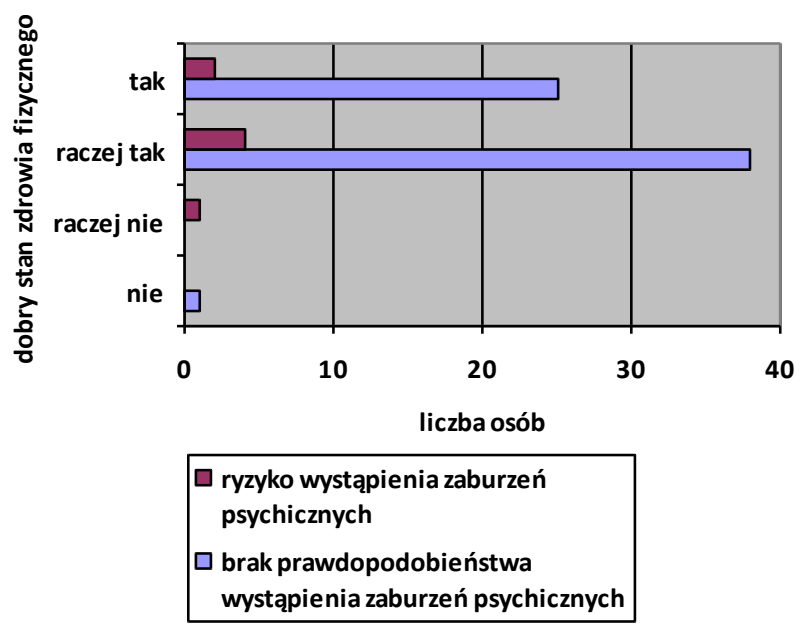

Rycina 1. Związek między dobrą oceną stanu zdrowia fizycznego a ryzykiem wystąpienia zaburzeń psychicznych, $\mathrm{N}=71$ Źródło: opracowanie własne.

Osoby określające swój stan zdrowia fizycznego jako zły nie wskazywały na występowanie symptomów świadczących o prawdopodobieństwie wystąpienia zaburzeń psychicznych. Można przypuszczać, że odczuwanie dobrego stanu zdrowia fizycznego nie wyklucza ryzyka wystąpienia zaburzeń psychicznych (ryc. 1).

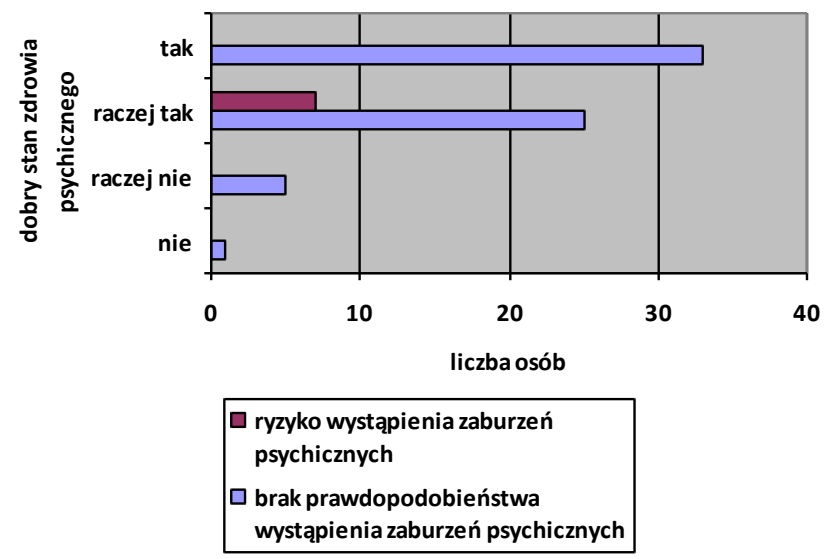

Rycina 2. Związek między oceną stanu zdrowia psychicznego a ryzykiem wystąpienia zaburzeń psychicznych, $\mathrm{N}=71$ Źródło: opracowanie własne.
Odnotowano prawdopodobieństwo wystapienia zaburzeń psychicznych jedynie w grupie osób, które stan swojego zdrowia psychicznego określiły jako raczej dobry (ryc. 2).

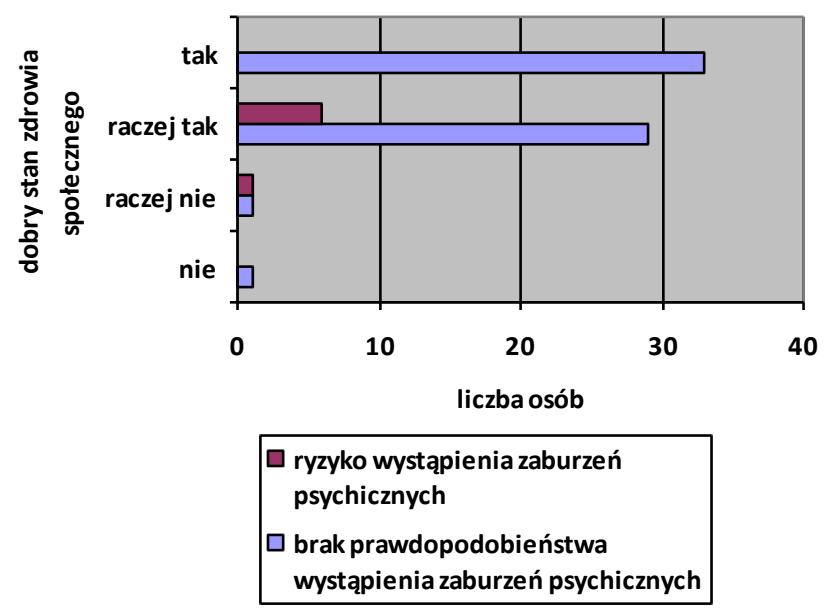

Rycina 3. Związek między oceną stanu zdrowia społecznego a ryzykiem wystąpienia zaburzeń psychicznych, $\mathrm{N}=71$. Źródło: opracowanie własne.

Ryzyko wystąpienia zaburzeń psychicznych odnotowano w grupie osób, które określiły swój stan zdrowia w wymiarze społecznym (wyrażony poprzez jakość relacji, poczucie wsparcia społecznego i stopień zaangażowania w życie społeczne) jako raczej dobry lub raczej zły (ryc. 3).

\section{Dyskusja}

Badane osoby definiowały świadomość zdrowotną jako: wiedzę o swoim stanie zdrowia, czynnikach prozdrowotnych, służących prowadzeniu zdrowego stylu życia oraz tych, które mają negatywny wpływ na zdrowie. Studenci wskazywali również na podejmowanie działań o charakterze profilaktycznym, przykładowo: dbałość o higienę ciała; zdrowe odżywianie; sen; ubiór dostosowany do pogody; regularne ćwiczenia fizyczne, spacery, taniec; przeprowadzanie badań kontrolnych: w tym morfologii krwi, cytologii; wizyty kontrolne u lekarzy specjalistów; szczepienia; przyjmowanie suplementów diety, unikanie używek. Helena Sęk (2000) powołując się na przeprowadzone badania, sugeruje, że badani są przekonani o znaczeniu zasobów odpornościowych i własnej kontroli zdrowia. Z tego sposobu myślenia wyłamuje się grupa kobiet $\mathrm{z}$ podstawowym 
wykształceniem, preferując model biomedyczny, obciążony brakiem sprawstwa i kontroli zdrowia. Wykształceni młodzi dorośli wskazują na istotną rolę kontroli własnego zdrowia i budowanie zasobów odpornościowych. Kontrola stanu zdrowia to również „skanowanie ciała”, wczytywanie się w swój stan psychiczny, odczytywanie samopoczucia w relacjach społecznych. Zdecydowanie zdrowie psychiczne wpisane jest w obszar tych doznań, stąd nie dziwi prawdziwość hipotezy pierwszej. Analiza wyników badań odnoszących się do drugiego pytania badawczego (hipoteza druga), pozwala wnioskować, że spostrzeganie swojego stanu zdrowia fizycznego jako dobry, nie przesądza o braku zaburzeń o charakterze psychicznym.

Potwierdziła się hipoteza trzecia, iż świadomość samopoczucia fizycznego i psychicznego jest związana $\mathrm{z}$ odczuwaniem symptomów somatycznych. Jak pisze Łosiak (2007, s. 33) poza przedstawicielami konstruktywizmu społecznego wszyscy badacze zajmujący się emocjami przyjmują, że zmiany somatyczne są integralnym składnikiem emocji. Znaczenie pozytywnej samooceny w wymiarze fizycznym i psychicznym dla oceny jakości życia badanych osób potwierdzają i inni badacze ( Rasińska, Nowakowska, 2013; Krawczyńska, Zięba E., Zięba P., NowakStarz, 2014). Gene Gendlin, amerykański filozof i psycholog, przedstawił koncepcję focusingu, uznanego za proces przemian w naszym wewnętrznym doświadczaniu. Proces focusingu umożliwia rozwiązywanie osobistych problemów, bardziej świadomie doświadczać otaczający nas świat, co pozwala na skuteczniejszą komunikację z innymi i samorealizację (Siems 2006, s. 10). Pojęcie wprowadzone przez Gendlina, to sposób odpowiedzi ciała na różne sytuacje. Wilhelm Reich stworzył pojęcie pancerza charakteru i pancerza mięśniowego, a także opisał związek pomiędzy postawami psychicznymi a napięciem mięśniowym. Terapie pracy z ciałem skupiają się na doznaniach cielesnych, co jest odmiennym podejściem w terapii, gdzie najczęściej pracuje się na poziomie werbalnym lub na poziomie obrazów. Doświadczenia felt sense to wrażenia w obszarze brzucha i klatki piersiowej, nazywane „rezonansem w ciele” lub „wewnętrzną aurą”. Wydaje się, że odczucia związane $\mathrm{z}$ napięciami, lękami, bólami, czy odwrotne, takie jak odprężenie, rozluźnienie się, odczuwane są niemal przez wszystkich ludzi.

Przeżycia pochodzą więc z różnych źródeł, zarówno somatycznych, jaki psychicznych, czy duchowych (transpersonalnych) (Vedfelt 2001). Wundt uważał, że uczucia są szczególnym stanem świadomości. Wczuwając się w sygnały ciała można te stany odczuć. Jak bardzo przeżywane uczucia, stres, emocje wpływają na nasz stan zdrowia zaświadcza obecność chorób o charakterze psychosomatycznym.

Została potwierdzona hipoteza czwarta, iż świadomość samopoczucia psychicznego jest związana z odczuwaniem niepokoju i bezsennością. Problemom psychicznym nierzadko towarzyszy niepokój i trudności w zasypianiu. Zarówno badania doro- słych, jak i dzieci dowodzą, że problemy ze snem przyczyniają się do rozwoju niektórych zaburzeń psychicznych. Badania neuroobrazowania i neurochemiczne umożliwiają potwierdzenie faktu, że dobry sen pomaga wspierać zarówno psychiczną, jak i emocjonalną odporność, a zakłócenia snu sprzyjają negatywnemu myśleniu i podatności na złe nastroje (Sleep..., 2009, s. 1). Zakłócenia snu są bardziej prawdopodobne u osób z zaburzeniami psychicznymi w porównaniu do osób w populacji ogólnej. Jednocześnie mogą zwiększać ryzyko rozwoju poszczególnych chorób psychicznych. Leczenie zaburzeń snu może pomóc złagodzić objawy problemu zdrowia psychicznego.

Podobnie potwierdzona została hipoteza piąta, iż świadomość samopoczucia zdrowia w wymiarze społecznym jest związana z zaburzonym funkcjonowaniem społecznym. Najprawdopodobniej łączy się to $\mathrm{z}$ rozumieniem funkcjonowania społecznego, które odnosi się do sytuacji problemowych naznaczonych niedoskonałościami zdrowia psychicznego. U młodych ludzi okresy zaburzeń nastroju często występują na przemian z okresami w miarę dobrego przystosowania (Radochoński, 2001). W obszarze społecznym widoczna jest ekspresja nieadekwatnych zachowań: trudności w komunikacji interpersonalnej, gadatliwość, nieprzemyślane wypowiedzi, skracanie dystansu społecznego w stosunku do innych. Dostrzec można formy pośrednie takie jak: absencja, konflikty wewnętrzne, okresy wzmożonej aktywności, brak inicjatywy, apatię (Białkowska, Mroczkowska, Zomkowska, Rakowska, 2014, s. 367).

Potwierdzona została hipoteza szósta, iż świadomość samopoczucia psychicznego jest związana z występowaniem objawów depresyjnych. Depresja jest jednym z najczęściej występujących zaburzeń psychicznych. Doprowadza do utraty zainteresowań, obniżenia nastroju, braku odczuwania przyjemności. Pojawia się spowolnienie procesów psychoruchowych, typowe objawy somatyczne oraz lęk. Ważnym staje się zła jakość snu bądź bezsenność.

Pietras i in., (2012, s. 163) przeprowadzili badania na grupie 385 studentów pedagogiki (Piotrków Trybunalski, Kielce) oraz 164 studentów ekonomii z wykorzystaniem Skali Depresji Becka. Wyniki wskazują, że studenci pedagogiki pięciokrotnie częściej byli obciążeni symptomami depresji, niż studenci ekonomii (dotyczy to przede wszystkim kobiet). Kontrola emocji jest niezbędną cechą zdrowia psychicznego. Szczególne znaczenie ma panowanie nad stanami o charakterze depresyjnym (Gross, MuAoz, 1995). Współczesne czasy dostarczają nam wiele powodów do niepokoju, a dostosowanie się do permanentnych zmian życiowych jest możliwe przy kontroli zakłóceń emocjonalnych, którym podlegamy (Konecki, 2007). Można przywołać wiele badań, które wskazują na częstsze występowanie depresji lub pojedynczych objawów depresyjnych u osób z rozpoznanymi chorobami somatycznymi. Występowanie choroby somatycznej traktowane jest jako czynnik ryzyka zachorowania na depresję (Dudek, Siwek, 2007). 
Badania Kok i in. (2013) dowiodły, że zdrowie fizyczne, więzi społeczne i pozytywne emocje wpływają na siebie w sposób dynamiczny. Zaobserwowano, iż pozytywne emocje wzmacniają sygnały nerwu błędnego. Emocje wpływają na wiele naszych procesów psychicznych, takich jak pamięć, podejmowanie decyzji, manifestują się w zachowaniach.

Ludzie regulują swoje emocje na wiele różnych sposobów. Nie wszystkie formy takich zachowań są z punktu widzenia dobrostanu zdrowe. Jedni próbują zmienić sposób myślenia o danym zdarzeniu, aby wywołać określone emocje, inni starają się tłumić emocje. Dowartościowanie działa szybko, przynosząc dobre rezultaty obserwowane w funkcjonowaniu społecznym i dobrym samopoczuciu. W życiu dorosłym częściej jednostki odwołują się do tej strategii, niż do tłumienia emocji, które w praktyce nie przynosi najlepszych rozwiązań (John, Gross 2004). Monshat K i in. (2013) dostrzegli rolę treningu uważności dla zwiększenia panowania nad emocjami. Możliwe jest osiągnięcie większego spokoju, równowagi oraz zaufania do własnych umiejętności radzenia sobie z negatywnymi emocjami. Osoby lepiej oceniające swój stan zdrowia psychicznego deklarują mniej problemów o charakterze depresyjnym.

\section{Wnioski}

Warto zauważyć, że świadomość samopoczucia fizycznego, psychicznego i społecznego współwystępuje z obszarami zdrowia psychicznego wyeksponowanymi przez Dawida Goldberga w kwestionariuszu GHQ-28.

Młodzi dorośli potrafią trafnie rozpoznać swój stan zdrowia w zakresie kondycji fizycznej, psychicznej i społecznej. Jednakże ryzyko wystąpienia w przyszłości zaburzeń psychicznych $(9,8 \%$ ogółu badanych) nie jest jednoznacznie przypisane do osób o złym samopoczuciu zdrowotnym. Trudno więc wskazać, iż samopoczucie zdrowotne jest głównym predyktorem prawdopodobieństwa wystąpienia zaburzeń psychicznych. Uzyskane wyniki badań własnych, prowadzone w grupie studentów, potwierdzają konieczność prowadzenia edukacji zdrowotnej skoncentrowanej na radzeniu sobie z problemami zdrowia psychicznego.

\section{Literatura:}

1. Białkowska, J., Mroczkowska, D., Zomkowska, E., Rakowska, A. (2014). Ocena zdrowia psychicznego studentów na podstawie Skróconego Kwestionariusza Zdrowia Pacjenta. Hygeia Public Health, 49(2), 365369.

2. Bishop, G.D. (2000). Psychologia zdrowia - zintegrowany umysł i ciało. Wrocław: Wyd. ASTRUM.

3. Cisek, M., Gniadek, A., Richter, B., Chmiel, I. (2004), Społeczno-kulturowe uwarunkowania zachowań zdrowotnych w rodzinie, Annales Universitatis Mariae Curie-Skłodowska, Lublin-Polonia, vol. LIX, Suppl. XIV, (68), sectio D, 103-107.

4. Czapiński, J. (2008), Osobowość szczęśliwego człowieka. W: J. Czapiński (red.), Psychologia pozytywna. Nauka o szczęściu, zdrowiu i cnotach człowieka (s. 359-379). Warszawa: Wydawnictwo Naukowe PWN.

5. Dudek, D., Siwek, M. (2007), Współistnienie chorób somatycznych i depresji. Psychiatria, 4(1), 17-24.

6. Freyberger, H.J., Schneider, W., Stieglitz, R.D. (2005). Kompendium psychiatrii, psychoterapii, medycyny psychosomatycznej. Warszawa: Wydawnictwo Lekarskie PZWL.

7. Gałecki, P., Orzechowska, A. (2014). Zaburzenia psychosomatyczne w ujęciu terapeutycznym. Wrocław: Wydawnictwo Continuo.

8. Gross, J.I., MuAoz, R.F. (1995), Emotion regulation and mental health. Clinical Psychology: Science and Practice, 2, 151-164. DOI: 10.1111/j.1468-2850.1995.tb00036.x.

9. Hong, H. (2011), Scale Development for Measuring Health Consciousness: Re-conceptualization. Pobrane z: www.instituteforpr.org/wp-content/uploads/caleDvlpment Measuring.pdf

10. John, O.P, Gross, J.J. (2004). Healthy and unhealthy emotion regulation: Personality processes, individual differences, and life span development. Journal of Personality, 72(6), 1301-1334.

11. Juczyński, Z. (2001), Narzędzia pomiaru w promocji i psychologii zdrowia. Warszawa: Pracownia Testów Psychologicznych Polskiego Towarzystwa Psychologicznego.

12. Kok, B.E., Kimberly, A., Coffey, K.A., Cohn, M.A., Catalino, L.I., Vacharkulksemsuk, T., Algoe, S.B., Brantley, M., Fredrickson, B.L. (2013). How positive emotions build physical health. Perceived positive social connections account for the upward spiral between positive emotions and vagal tone. Psychological Science, 24(7), 1123-32. DOI: 10.1177/0956797612470827.

13. Konecki, K.T. (2007). Praca nad ciałem i emocjami w praktyce hatha-jogi. W strone „kultury emocjonalnej” bez emocji. W: K.T. Konecki, B. Pawłowska (red.), Emocje w życiu codziennym. Analiza kulturowych, społecznych i organizacyjnych uwarunkowań ujawniania i kierowania emocjami (s. 67-88). Łódź: Wydawnictwo Uniwersytetu Łódzkiego,

14. Korzeniowska, E. (1997). Zachowania zdrowotne i świadomość zdrowotna w sferze pracy. Łódź: Instytut Medycyny Pracy im. prof. Dra med. Jerzego Nofera, Krajowe Centrum Promocji Zdrowia w Miejscu Pracy.

15. Krawczyńska, J., Zięba, E., Zięba, P., Nowak-Starz, G. (2014). Umiejscowienie kontroli zdrowia i samoocena zdrowia młodzieży szkół ponadgimnazjalnych, Problemy Pielęgniarstwa, 22(4), 445-452. 
16. Łukasik, I.M. (2011). Świadome ciało w podróży bez granic. Lublin: Wyd. Kaprint.

17. Makowska, Z., Merecz, D. (2001). Polska adaptacja Kwestionariuszy Ogólnego Stanu Zdrowia Davida Goldberga: GHQ-12 i GHQ-28. W: Ocena zdrowia psychicznego na podstawie badań kwestionariuszami Davida Goldberga. Podręcznik dla urzędników kwestionariuszy GHQ-12 i GHQ-28 (s. 201-210). Łódź: Oficyna Wydawnicza Instytutu Medycyny Pracy im. prof. J. Nofera.

18. Michalska-Leśniewicz, M., Gruszczyński, W. (2010). Czynniki psychologiczne w depresji. Psychiatria, 7(3), 95-103.

19. Monshat, K., Khong, B., Hassed ,C., Vella-Brodrick, D., Norrish, J., Burns, J., Herrman, H. (2013). A conscious control over life and my emotions. Mindfulness practice and healthy young people. A qualitative study. Journal of Adolescent Health, 52(5), 572-577.

20. Ocena zdrowia psychicznego na podstawie badań kwestionariuszem Dawida Goldberga. Podręcznik dla użytkownika Kwestionariusza GHQ-12 i GHQ-28 (2001). Łódź: Instytut Medycyny Pracy im. prof. J. Nofera.

21. Ostrzyżek, A., Marcinkowski, J.T. (2012). Biomedyczny versus holistyczny model zdrowia a teoria i praktyka kliniczna. Problemy Higieny i Epidemiologii, 93(4), 682-686.

22. Pietras, T., Witusik, A., Panek, M., Zielińska-Wyderkiewicz, E., Kuna, P., Górski, P. (2012). Intensity of Depression in Pedagogy Students. Pol Merkur Lekarski, 32(189), 163-166.

23. Puchalski, K. (1997), Zdrowie w świadomości społecznej. Łódź: Instytut Medycyny Pracy im. prof. Dra med. Jerzego Nofera Krajowe Centrum Promocji Zdrowia w Miejscu Pracy.

24. Radochoński, M. (2001). Podstawy psychopatologii dla pedagogów. Rzeszów: Wydawnictwo Uniwersytetu Rzeszowskiego.

25. Rasińska, R., Nowakowska, I., Nowomiejski J. (2013). Diagnoza stanu zdrowia studentów i ich opinie o zagrożeniach zdrowotnych, Pielegniarstwo Polskie, 2(48), 79-84.

26. Rymaszewska, J., Dobrzyńska, E., Kiejna, A. (2006). Funkcjonowanie społeczne i niepełnosprawność definicje, narzędzia oraz znaczenie kliniczne w psychiatrii. Postępy Psychiatrii i Neurologii, 15(2), 99-104.

27. Segal, J. (1997). Jak pogłębić inteligencję emocjonalną: program treningu ujawniającego potęgę uczuć i intuicji. Warszawa: Santorski\&Co Agencja Wydawnicza S.p. z.o.o.

28. Sęk, H. (2000). Subiektywne koncepcje zdrowia, świadomość zdrowotna a zachowania zdrowotne i promocja zdrowia. Sbornlk Prací Filozofické Fakulty Brnênské Univerzity Studia Minora Facultatis Philosophicae Universitatis Brunensis 4, 17-34.

29. Siems, M. (2006). Ciało zna odpowiedź. Warszawa: Jacek Santorski\&Co Agencja Wydawnicza S.p. z.o.o.

30. Sieradzki, P. (2007). Emocje w życiu codziennym a a konstruowanie ładu poznawczego i społecznego. Kilka uwag opartych na empirycznej teorii „społeczeństwa doznań” Gerharda Schulze. W: K.T. Konecki, B. Pawłowska (red.), Emocje w życiu codziennym. Analiza kulturowych, społecznych i organizacyjnych uwarunkowań ujawniania i kierowania emocjami (s. 145-160). Łódź: Wydawnictwo Uniwersytetu Łódzkiego.

31. Sleep and mental health (2009). Harvard Mental Health Letter, 26(1), JU www.health.harvard.edu

32. Solovey, P., Mayer, J.D., Caruso, D. (2008). Pozytywna psychologia inteligencji emocjonalnej. W: J. Czapiński (red.), Psychologia pozytywna. Nauka o szczęściu, zdrowiu i cnotach człowieka (s. 380-398). Wydawnictwo Naukowe PWN, Warszawa,

33. Starzyńska-Kościuszko, E. (2010). Holistyczna (całościowa) koncepcja zdrowia. Zdrowie jako wartość. Humanistyka i Przyrodoznawstwo, 16, 319-326

34. Szyszko-Bohusz, A. (2013). Pedagogika holistyczna oraz samodoskonalenie osobowości i bezpieczeństwo w dobie globalizacji. The Polish Journal of the Arts and Culture, 7(4), 201-217.

35. Vaillant, G.E. (2012). Pozytywne zdrowie psychiczne: czy istnieje definicja międzykulturowa? Postępy Psychiatrii i Neurologii, 21(4), 229-250.

36. Vedfelt, 0. (2001). Poziomy świadomości. Poznaj potencjał swojego umysłu, Warszawa: Eneteia.

37. Woynarowska, B. (red.) (2017). Edukacja zdrowotna. Podstawy teoretyczne. Metodyka. Praktyka. Warszawa: PWN. 